\title{
CROSS-CULTURAL TRAINING FOR DUTCH EXPATRIATES GOING TO INDIA.
}

\author{
Simone J. van Zolingen (PhD)*, Caroline Essers (PhD)**, Lisan Vermeer (MSc)*** \\ *Assistant Professor of Human Resource Development \\ **Assistant Professor Strategic HRM \\ ***Lawyer / Attorney at law at Bogaerts \& Groenen Advocaten \\ Institute for Management Research \\ Radboud University Nijmegen \\ P.O.Box 9108 \\ 6500 HK Nijmegen \\ The Netherlands \\ E-mail: S.vanZolingen@fm.ru.nl \\ Phone +31(0)243616252
}

Paper for the $11^{\text {th }}$ International Human Resource Management Conference 9-12 June 2010, Aston Business School, Birmingham UK 


\title{
Cross-Cultural Training for Dutch expatriates going to India.
}

\author{
Simone J. van Zolingen \& Caroline Essers \\ Institute for Management Research \\ Radboud University Nijmegen
}

\author{
Lisan Vermeer \\ Bogaerts \& Groenen Advocaten
}

\begin{abstract}
The aim of this study is to gain insight in the challenges Dutch expatriates encounter during their stay in India, and in the way CCT can be improved in order to handle these challenges adequately. For this explorative in depth study CCT was split up in five areas: adjustment to work; adjustment to interacting with host country nationals; adjustment to the general non-work environment, adjustment to the Indian culture, and adjustment to the Indian context. Eighteen Dutch expatriates were interviewed. Data analysis included discursive interpretation of relevant quotes. A number of elements that can be improved in received CCT were located in the five above mentioned areas.
\end{abstract}

When investing in a foreign country most companies send some employees, especially managers, from the home country to that foreign country. This phenomenon is referred to as expatriation: “headquarters employees working abroad in one of the firm's subsidiaries for a limited period of usually two to five years” (Harzing, 2001, p 366). Nowadays, nearly $80 \%$ of the large and midsize companies send employees abroad (Black \& Gregersen, 1999). The management of these expatriates is one of the main tasks of international human resource management (Stahl \& Björkman, 2006). When expatriates embark on their foreign assignments, they are confronted with many difficulties that often result in the expatriate deciding to leave the host country before the conclusion of his or her assignment. These early return rates have been estimated to be as high as $40 \%$ (Black and Mendenhall (1990). The focus of this study is on the crosscultural training (CCT) of expatriates that is given for improving the adjustment of expatriates in the host country. CCT has been defined as an educative process focused on promoting intercultural learning through acquisition of behavioural, cognitive, and affective competencies required for effective interactions across diverse cultures (Landis \& Brislin in Littrell and Salas, 2005). CCT has been identified as a major technique for improving the cross-cultural effectiveness of managers. But very little empirical evidence 
exists to support this claim. Lack of a unitary theoretical framework has hindered systematic research into CCT. Social learning theory (Bandura in Littrell, 2006), the dynamics of adjustment (Church in Littrell, 2006, Selmer in Littrell, 2006) and, culture shock (Church in Littrell, 2006) have been used by researchers to explain how CCT facilitates the effectiveness of expatriate employees. However, researchers have failed to empirically test these theories. Most of the few empirical studies that address the effectiveness of CCT provide support for the belief that CCT facilitates an expatriate's success on a foreign assignment. Black and Mendenhall (1990 p.120) for example conclude in their literature review of 29 studies: "Thus, the empirical literature gives guarded support to the proposition that CCT has a positive impact on cross-cultural effectiveness.” More recent literature confirms this view (Forster, 2000, Anderson, 2003, 2005, Morris and Robie, 2001, Waxin and Panaccio, 2005). Research indicates that CCT is positively related to adjustability and cross-cultural adjustment is in turn positively related to performance and negatively to early return rates. CCT enhances skill development of self-maintenance skills, interpersonal skills, and cognitive skills, and CCT is positively related to the development of self-confidence and overall feelings of well-being (Littrell et al., 2006). At present researchers believe that many factors potentially moderate the relationship between CCT and expatriate performance, including timing of the training (predeparture, postarrival), family characteristics (marital status, children, spousal adjustment), job characteristics (task difficulty, job discretion, role conflict, workload, and adjustment-inhibiting or facilitating factors), organizational attributes (postarrival CCT, organizational cultural differences, social support), individual attributes (cognitive flexibility, adaptability, tolerance for ambiguity, nonethnocentrism, extraversion, positive self image, social skills, open mindedness, cultural empathy, ability to deal with psychological stress), cultural toughness (size of cultural differences), training rigor (training method and training length: low, moderate, high) (Littrell et al., 2006). Despite the many claims by researchers that CCT is necessary to increase the probability of success on foreign assignments, MNCs are not listening. Although estimates vary, only approximately 30\% of MNCs offer their employees CCT, and most of these programs are 1-day briefing sessions (Littrell et al, 2006). Further, it is still not 
clear whether CCT in a traditional form offers expatriates the needed insights and skills to succeed (Osman-Gani, 2000).

Being one of the countries attracting most expatriates (Amin and Mattoo, 2008, Rothermund, 2008), this study aims to investigate if and in what ways expatriates going to India are trained, whether there are problems arising from this kind of training and in what ways these problems can be solved. In order to achieve this research aim, this paper questions: What kind of challenges do the Dutch expatriates encounter during their stay in India, and how can CCT courses be improved so that Dutch expatriates are able to handle these challenges adequately? Our study contributes to a better understanding of the relation between expatriation, training, performance and culture.

\section{THEORY}

CCT has process and content aspects. Process aspects are CCT delivery approaches and instruction strategies. Different CCT delivery approaches can be distinguished (Bhawuk and Brislin, 2000, Littrell et al. 2006, Russell, 2006) such as for example job expectations (providing the expatriate with accurate job expectations), didactic training (factual information regarding working conditions, living conditions of the host country, and cultural differences), interaction training (overlaps, on-the-job training supervised by an experienced expatriate already occupying the same position), cultural awareness training (raising understanding of ones own culture to appreciate cultural differences), attribution training (providing learning to comprise explanations of host national behavior from the host-culture point of view), cultural assimilation (simulated experience via role play or negotiation simulations), language training, sensitivity training (developing a flexible attitude toward host country nationals, HCNs) and training of the family (for spouse and other family members). Also CCTs have different instruction strategies such as behavior modification, simulations, expositive instruction and field experience (Baumgarten in Forster, 2000). Looking at the content of CCT researchers agree that three aspects are essential; the degree of personal adjustment to the new host environment, the degree of professional effectiveness in accomplishing business responsibilities, and the degree of interpersonal adjustment (Littrell \& Salas, 2005). 
In expatriate management 'adjustment' to the host country is essential (Zucal \& Talani, 2004). But what does this adjustment exactly entail? Black \& Gregersen (1991 p.498) define adjustment as the "degree of a person's psychological comfort with the various aspects of a new setting”. According to Black et al. (1991), there are three indicators of international adjustment: adjustment to the general non-work environment, adjustment to work, and adjustment to interacting with host country nationals (HCNs). In order to achieve this international adjustment, a CCT course can be an important tool to learn to handle challenges such as culture shock, isolation, homesickness, problems with housing, differences in work-related norms, different gender roles, differences in health care, a different language and different customs (Morley \& Flynn, 2003, Mendenhall \& Oddou, 1985, 1986). Contents of CCT courses mentioned in the literature are not only as above mentioned, job factors, relations with HCN's, and the non-working environment (for example language, bureaucracy, and safety), but also the context of the country (e.g. religion, poverty) and the culture of the country (Brewster \& Scullion, 1997, Forster, 2000, Russell, 2006). In this paper culture is defined as: "the collective programming of the mind which distinguishes members of one group or category of people from another" (Hofstede, 1991 p.5). Having an idea about how we can perceive culture, the next question is how it can be studied. Since, culture remains partly implicit, it is not always easy to 'measure' a particular culture. However, there are a number of theories available on this topic. While discussing two of them, only those theories which stress the comparable aspects of culture, the so called 'etic' studies, will be discussed. The opposite of the etic studies are the emic studies, which entail rich data, but are hardly comparable since they are more subjective than data collected in etic research (Koen, 2005). Since we want to find out what the influence of the Indian culture and context is on problems and challenges experienced by Dutch expatriates, it seems better to stress the comparable aspects of culture. Therefore only etic theories such as the theory of Hofstede (1991) and the theory of Hampden-Turner \& Trompenaars (2000) will be used. Although we acknowledge and are aware of the critique on Hofstedes dimensions, such as flaws in his methodological assumptions (McSweeney, 2002) for example the assumption of equating nation with culture and the difficulty, and limitations of an understanding of culture by 
means of numeric indices and matrices (Baskerville, 2003), we still believe that his dimensions are valid for our study.

Hofstede distinguishes five dimensions on which cultures can be measured and compared 1) power distance, that describes the extent to which "the less powerful members of institutions and organizations within a country expect and accept that power is distributed unequally" (Hofstede, 1991: 262). One of the implications of this dimension is that the organizational structures of organizations in high power distance countries are likely to be more centralized as those in low power distance countries; 2) uncertainty avoidance, describes the extent to which "the members of a culture feel threatened by uncertain or unknown situations” (Hofstede, 1991: 263). For organizations this means that in low uncertainty avoidance countries there is tolerance for ambiguity in structures and procedures, while in high uncertainty avoidance countries there is a highly formalized conception of management; 3) individualism versus collectivism, describes whether "the ties between individuals are loose, with everyone being expected to look after himself or herself and his or her immediate family only” (individualism), or whether "people from birth onwards are integrated into strong, cohesive in-groups, which throughout people's lifetime continue to protect them in exchange for unquestioning loyalty” (collectivism) (Hofstede, 1991: 260-261). In collectivist countries the relationship between the employer and the employee is basically moral, like a family link. In individualistic countries on the other hand, the relationship between the employer and the employee is a business deal in a labor market; 4) masculinity versus femininity, describes whether "social gender roles are clearly distinct: men are supposed to be assertive, tough, and focused on material success; women are supposed to be more modest, tender, and concerned with the quality of life" (masculinity), or whether "social gender roles overlap; both men and women are supposed to be modest, tender, and concerned with the quality of life” (femininity) (Hofstede, 1991: 261-262). In masculine countries managers are expected to be decisive, firm, assertive, aggressive, and competitive; while in feminine countries managers are expected to use intuition, to deal with feelings and to seek consensus; 5) long-term versus short-term orientation. This dimension is related to the "fostering of virtues oriented towards future rewards, in particular perseverance and thrift" (long-term orientation) versus "the fostering of virtues 
related to the past and the present, in particular respect for tradition, preservation of “face”, and fulfilling social obligations” (short-term orientation) (Hofstede, 1991: 261263). In short-term oriented countries in business the short-term results are important: the bottom line; while in long-term oriented countries in business the building of relationships and market position are important.

TABLE 1

\section{Comparison of the Dutch culture and the Indian culture on the dimensions of Hofstede and Hampden-Turner \& Trompenaars}

\begin{tabular}{|c|c|c|c|c|c|c|}
\hline Dimensions of culture & India & Hof & $\mathrm{H} \& \mathrm{~T}$ & The Netherlands & Hof & $\mathrm{H} \& \mathrm{~T}$ \\
\hline Power distance & High power distance & 77 & & $\begin{array}{c}\text { Low } \\
\text { power distance }\end{array}$ & 38 & \\
\hline Uncertainty avoidance & Low uncertainty avoidance & 40 & & $\begin{array}{l}\text { Moderate } \\
\text { uncertainty } \\
\text { avoidance }\end{array}$ & 53 & \\
\hline $\begin{array}{c}\text { Individualistic vs. } \\
\text { collectivistic/ } \\
\text { communitaristic }\end{array}$ & Collectivistic/communitaristic & 48 & 36 & Individualistic & 80 & 65 \\
\hline $\begin{array}{l}\text { Masculinity vs. } \\
\text { femininity }\end{array}$ & Masculine & 56 & & Feminine & 14 & \\
\hline $\begin{array}{l}\text { Short-term vs. long- } \\
\text { term orientation }\end{array}$ & Short-term orientation & 61 & & $\begin{array}{l}\text { Long term } \\
\text { orientation }\end{array}$ & 44 & \\
\hline $\begin{array}{l}\text { Specific vs. } \\
\text { diffuseness }\end{array}$ & Diffused & & 46 & Specific & & 91 \\
\hline $\begin{array}{l}\text { Universalistic vs. } \\
\text { particularistic }\end{array}$ & Particularistic & & 54 & Universalistic & & 90 \\
\hline $\begin{array}{l}\text { Ascription vs. } \\
\text { achieved status }\end{array}$ & Ascription oriented & & 57 & $\begin{array}{l}\text { Achievement } \\
\text { oriented }\end{array}$ & & 30 \\
\hline $\begin{array}{l}\text { Sequential vs. } \\
\text { synchronous } \\
\text { view of time }\end{array}$ & Sequential view of time & & 4.03 & $\begin{array}{l}\text { Slightly sequential } \\
\text { view of time }\end{array}$ & & 4.63 \\
\hline
\end{tabular}


Hampden-Turner \& Trompenaars (2000) add three different dimensions to the five dimensions distinguished by Hofstede: 1) universalism versus particularism. In a universalistic culture, a judgment of what is good or what is true applies to every situation. Treating friends better than others is nepotism and unethical. In a particularistic culture, circumstances and relationships influence judgments of what is good or true. Treating friends better than others is normal and ethical. 2) specificity versus diffuseness, which refers to the level of particularity or wholeness used by a culture to define different constructs. Some cultures analyze phenomena into specifics; they use parts, facts, targets, tasks, numbers, units, points etc. Other cultures integrate and configure these details into diffuse patterns, relationships, and wider contexts; they focus on conceptual wholeness; 3) achieved status versus ascribed status refers to the fact that in some societies someone gets his status on the basis of achievement (achieved status), while in other societies someone gets his status on the basis of durable characteristics such as age (ascribed status); 4) sequential versus synchronous time. In a sequential culture, the focus is on rational efficiency. The importance is on how to get things done in the shortest possible sequence of passing time, and to stick to schedules. A synchronic culture on the other hand, allows parallel activities and is less focused on punctuality. It is more oriented towards effectiveness than towards efficiency, and interpersonal relationships are more important than schedules.

Comparing the Dutch and Indian culture on these nine dimensions shows that the Dutch culture and the Indian culture differ a lot on seven of the nine dimensions (Table 1). Only the dimensions uncertainty avoidance and sequential vs. synchronous view of time are not expected to cause problems for the Dutch expats going to India.

\section{METHOD}

The population interviewed for this study consists of Dutch expatriates who are or have been living and working in India. This means there were two selection criteria: Dutch nationality, in order to be able to anticipate on expected problems and challenges between the Indian culture and the Dutch culture; and the expatriate needed to live and work or have been living and working in India. Since very little knowledge of the relation between expatriation, training, performance, and culture was available an exploratory 
study was chosen. For such a study the saturation effect is reached at 15 interviews (Wester \& Peters, 2004).

At first only a few expatriates were found via expatriate forums,. Next snowball sampling, which "involves using informants to identify cases that would be useful to include in the study” (Kemper et al., 2003: 283), has been applied in order to find more respondents. This finally resulted in 18 respondents. The respondents worked for private as well as for public companies in industry and in service, in (car, oil, pc) factories, in banks, in insurance companies and in hospitals.

Several distinctions have been made within the research sample based on gender; country of origin of the company and whether the respondent was/is living in a rural or urban area. From the 18 respondents, four expatriates were female, and 14 expatriates were male. Six expatriates work(ed) for an Indian company, two expatriates work(ed) for a Dutch company located in India, and 10 expatriates work(ed) for a multinational. Fourteen expatriates are/were living in an urban area, and 4 expatriates are/were living in a rural area.

TABLE 2

Description of respondents

Respondent Gender expat Country of origin of company Location company

\begin{tabular}{cccc}
\hline Anne & Female & Indian & Rural \\
Bob & Male & Multinational & Urban \\
Carine & Female & Indian & Rural \\
Dorian & Female & Indian & Urban \\
Eddy & Male & Indian & Rural \\
Fred & Male & Multinational & Urban \\
Greg & Male & Multinational & Urban \\
Hans & Male & Dutch & Urban \\
Ian & Male & Indian & Urban \\
John & Male & Multinational & Urban \\
Klaas & Male & Multinational & Urban \\
Lionel & Male & Multinational & Urban \\
Max & Male & Indian & Rural \\
Niels & Male & Multinational & Urban \\
Otto & Male & Multinational & Urban \\
Piet & Male & Multinational & Urban \\
Queen & Female & Multinational & Urban \\
Ronald & Male & Dutch & Urban \\
\hline
\end{tabular}


A semi-structured interview has been used to obtain data from Dutch expatriates who are/have been living in India. The interview questions were derived from the main concepts mentioned in the theory: international adjustment, CCT, and the Indian context and culture. In the first place the respondent was asked if he/she received a pre-departure training course, what kind of training course it was and what the contents of the course were and what the opinion of the expat was about the training course. The concept of international adjustment has been operationalized based on Black et al. (1991) (international adjustment $=$ adjustment to work; adjustment to interacting with host country nationals; adjustment to the general non-work environment). Questions were for example: "Was information about work adjustment part of the training course? Did it help in practice? What elements were missing?” Further the Indian context was operationalized by questioning the influences of religion, poverty and the caste system upon the daily lives of the managers (Mehta \& Shah, 2003, Milner, 1994). The Indian culture furthermore was operationalized following the cultural dimensions of Hofstede (1991) and Hampden-Turner \& Trompenaars (2000) (see Table 1).

Data analysis existed of the following steps. First the recorded data, gathered from the interviews, were converted into verbatim transcripts. Next, before the actual analysis started, codes (such as for example existence of pre-departure training, content of CCT, type of CCT, opinion expatriate about CCT, impact of CCT regarding adjustment to work, absence of elements in received CCT regarding adjustment to interacting with HCNs, religion, corruption, power distance, uncertainty avoidance) were formulated with help of the theoretical framework. Subsequently the interviews were codified with help of these codes. The codification of the transcripts helped to structure the data and ensured to some extent the comparability of the conducted interviews. The last step taken was composing a matrix for each respondent in which all the codified elements were gathered. From the codified data we derived the most important themes. Within these themes we selected the illustrative quotes to make sense of these themes. These quotes were discursively interpreted to understand what, why and how things where said by the expatriates (Potter \& Whetherell, 1987). 


\section{FINDINGS}

The aim of this study was to gain insight in the challenges Dutch expatriates encounter during their stay in India, and in the way the CCT can be improved so that Dutch expatriates are able to handle these challenges adequately. This central issue is described in this section and based on the information provided by the expatriates.

From the 18 interviewed expatriates, 6 of them (respondent Anne, Carine, Eddy, Ian, Klaas, and Max) received some form of CCT, varying from one day to several weeks. Only one respondent Klaas, works for a multinational, the other respondents who have had CCT all work for an Indian company. These six respondents indicated that training should not be too long, that it can never be perfect for all expatriates, that it is fun to find out things yourself as well, and that you should be aware of the risk of getting too superficial.

The received CCTs have in common that they included cultural awareness training and attribution training. Further some of the received CCTs also included didactic training and language training. Instruction strategies used where predominantly participatory approaches such as role play and simulations that require active participation of the expatriate. One expatriate mentioned the use of case studies.

In this study the challenges Dutch expatriates encounter during their stay in India have been investigated regarding five areas: work, interacting with HCNs, the general non-work environment, the Indian culture, and the Indian context. From the empirical data it seems that for each of these areas a number of elements can be identified as a possible source for problems and challenges. These elements have been summarized in table 3 (for work, interacting with HCNs, and for the general non-work environment) and table 4 (for the Indian culture, and the Indian context). The extent to which these elements should be treated in a CCT, according to the expatriates interviewed for this study, is included (“just mention”, and "treat extensively).

The elements which should form the basis of a CCT for Dutch expatriates going on assignment in India can be split up in three groups, namely international adjustment, the Indian culture, and the Indian context.

International adjustment consists of adjustment to work, adjustment to interacting with HCNs, and adjustment to the general non-work environment (see Table 3). 
TABLE 3

Level of attention needed for different elements in CCT for Dutch expatriates in India (part 1)

\begin{tabular}{|c|c|c|}
\hline \multicolumn{3}{|c|}{ Elements in CCT for Dutch expatriates in India } \\
\hline \multicolumn{3}{|c|}{ International adjustment } \\
\hline $\begin{array}{l}\text { Regarding work } \\
\text { Treat extensively }\end{array}$ & Regarding interacting with HCNs & $\begin{array}{l}\text { Regarding the general non-work } \\
\text { environment } \\
\text { Treat extensively }\end{array}$ \\
\hline \multirow{2}{*}{$\begin{array}{l}\text { Indians have a passive attitude in } \\
\text { an office environment }\end{array}$} & (1) Interacting with HCNs in a & Language \\
\hline & $\begin{array}{l}\text { Social environment: } \\
\text { Just mention }\end{array}$ & Patience \\
\hline Hierarchical thinking & Habits of Indians: non verbal body & Being on your own (isolation) \\
\hline Bureaucracy & language & Bureaucracy \\
\hline \multirow{3}{*}{$\begin{array}{l}\text { Corruption } \\
\text { Background of the country, its } \\
\text { development, and the Indian } \\
\text { business culture. }\end{array}$} & $\begin{array}{l}\text { Indians don't like to say no or } \\
\text { contradict }\end{array}$ & Corruption \\
\hline & Behavioural aspects of being in & Reading local newspapers \\
\hline & India. & Power cuts \\
\hline \multirow[t]{6}{*}{ Intercultural communication } & Language & Unwelcome feeling \\
\hline & Hierarchy & Safety \\
\hline & $\begin{array}{l}\text { Differences in behavior towards } \\
\text { men and women }\end{array}$ & $\begin{array}{l}\text { Practical issues: } \\
\text { - Shortlists displaying highlights for }\end{array}$ \\
\hline & Intercultural communication & $\begin{array}{l}\text { the region including known social } \\
\text { places for westerns } \\
\text { - Contacts of importance such as the } \\
\text { Dutch embassy }\end{array}$ \\
\hline & $\frac{\text { (2) Interacting with HCNs as }}{\text { domestic personnel }}$ & $\begin{array}{l}\text { - How to connect telephone and } \\
\text { internet }\end{array}$ \\
\hline & $\begin{array}{l}\text { Treat extensively } \\
\text { The expatriate really has to be a } \\
\text { boss towards the domestic } \\
\text { personnel. }\end{array}$ & $\begin{array}{l}\text { - Buying train tickets via } \\
\text { www.irctc.co.in } \\
\text { - Cheap plane tickets via } \\
\text { www.yathra.com } \\
\text { - Cabs }\end{array}$ \\
\hline
\end{tabular}

Adjustment to work should definitely be an element of CCT for expatriates leaving for India and this element should be treated extensively according to 10 respondents. Respondent Max, who is working for an Indian company in a rural area, says for example: "if you come somewhere, in a country where you don't know the habits, it is useful that you can make a distinction between things you can avoid and things you 
simply can't avoid. I mean, it isn't always your fault."(...) "When I had to deal in India with the situation that people didn't pay attention to me, I found it nice to know that this is quite a normal situation. So in that sense the training definitely helped me."

This quote shows that CCT can make that you feel yourself at home quicker and that you know a bit more about the habits and how to react to those habits. However, five respondents did not give their opinion about whether they think CCT (could have) helped them in their adjustment to work, and 3 respondents indicate that they think CCT did or could not have any influence on adjustment to work.

From the latter group, Hans, working for a smaller Dutch firm in an urban area, indicates: "I don't think CCT could have helped me since I already had some experience and then it's quite easy to adjust." Carine, working for an Indian company in a rural area, indicates: "the CCT I received was not really useful. But of course I'm influenced by my earlier experiences in a foreign country." So because of earlier experiences with working in a foreign country, these respondents indicate that they are prepared for working in India as well. This indicates that when future expatriates already have some experiences with working in another country, this can influence their opinion about the usefulness of CCT regarding work. It can be seen that neither the company the expatriate is working for nor the place the company is located seems to influence the opinion that CCT did or could not have any influence on adjustment to work since the three expatriates who indicate this are all working for different kind of companies. This might indicate that the influence of CCT on work is something personal, not influenced by the company the expatriate is working for. It is not necessarily the case that expatriates who have worked in foreign countries before do not need CCT. Respondent Lionel, working for a multinational, had for example already experience with working in another country and culture as well when he went to India, and he still indicates that CCT could have been useful: "if I would have had training it could have helped me I think." This shows that previous experiences can change the opinion of the expatriate about CCT, but not necessarily does change it. The influence of previous experiences on adjustment to work is personal, and differs from person to person. Moreover, each country has its own culture, and although previous experiences can have the result that the expatriate already knows general elements of being an expatriate and about how to cope with a different 
culture, they still do not know anything specifically about the Indian culture. In addition, more than half of the respondents explicitly indicates that CCT has helped or could have helped them regarding adjustment to working in India. Therefore, in our opinion, adjustment to work should be an element of CCT for expatriates leaving for India, regardless previous experiences the expatriates have.

Regarding adjustment to interacting with HCNs 11 respondents indicate that they think CCT helped them (in case they received CCT) or could have helped them (in case they did not receive CCT) in their adjustment to interacting with HCNs. However, there should be made a distinction between interacting with HCNs on a social level and interacting with HCNs as domestic personnel. Regarding interaction with HCNs on a social level, it is important to include at least some basic elements, some basic dos and don'ts. Regarding interacting with HCNs as domestic personnel, the CCT definitely needs to focus extensively on this subject to avoid problems in this area. Klaas indicates for example: "people with 'less' respected jobs, drivers, gardeners, guards etc, expect their bosses to behave 'bossy'.” Niels says: “(...) if you get domestic personnel and you give them a lot of freedom, it will go terribly wrong. And with terribly wrong I mean that they smash each other's head in and that kind of stuff. You have to experience it yourself, but it is useful to know in advance. It happened to me as well. I never had any problems so on a certain moment I gave them more freedom. Well, they stole everything from the garden, each day the diesel generator was empty, the electricity in India is very bad so you need a generator... and on one night I came home and they drank all my liquor so they were completely drunk and they were literally smashing each other's head in.”. This quote shows Niels experience that Indian personnel sometimes finds it difficult to handle more freedom at work. However we should note that we cannot generalize this experience to the Indian culture and we should refrain from essentialist conclusions.

Adjustment to the general non-work environment should also be treated extensively in the CCT program. It is useful to include certain elements of the general non-work environment for all expatriates, regardless the kind of company they are working for and whether the company is located in an urban or a rural area in India. John, working for a multinational in an urban area, indicates: "such training should especially be informative and focused on practical issues. What can you expect on the first day 
you're in the country?" Lionel, working for a multinational in an urban area, says about CCT regarding to the general non-work environment: "I think that training in advance is less effective, it should be more something from the company in India, some sort of instruction course there. That would have helped me; it now took me for example two months to find out where to buy some meat." Carine, working for an Indian company in a rural area, indicates: "When you're really going to live there (in India), it's comfortable if someone hangs around with you for a couple of days and shows you things like here you can buy this, there you can buy that." Interpreting these utterings, not everybody agrees training should take place beforehand, moreover (only) John, Lionel and Carine agree that guidance of the expatriates is more important while emphasizing to have an 'instruction course' on location and 'someone hanging around'.

The second group of elements concerns the Indian culture (see Table 4). Power distance should be discussed extensively in a CCT program since it is likely to be a source of problems and challenges for Dutch expatriates working and living in India. Anne, working for an Indian company in a rural area, for example says: "he is really the boss and I have to wait like a dog and I'm not used to that." Lionel, working for a multinational in a urban area, indicates: "on the job, it is really hierarchical there and if you're a manager they'll do what you say and then it is important that you give orders, much more commanding and much more controlling and you also have to explain what they have to do because they're really good in executing tasks and that's the way they're raised and how their culture is like." Both Anne and Lionel experience a strict line between managers and their subordinates; and that the power is exclusively at the level of the managers, as they use very extreme expressions such as 'waiting like a dog', 'giving orders'and 'commanding'. So at least for them, India seems much more hierarchical than the Netherlands. We found that the ascription oriented nature of Indians should just be mentioned in a CCT. Although the differences on this dimension between India and The Netherlands are quite large, none of the expatriates indicate that they have (had) problems regarding this dimension of the Indian culture. This also goes for short term orientation. The dimension sequential vs. synchronous view of time on the other hand should be treated extensively in a CCT program since the results of this study show that this dimension is likely to give rise to problems and challenges. When asking the respondents 
whether they agreed with the statement that India has a sequential view of time, most of them did not agree. Some of them even started laughing. It seems that the opposite is true; this is indicated by 15 of the 18 respondents. Klaas indicates: "there has been no cultural awareness training which has prepared me for life in India and how indirect and inefficient they can be in this country. The fact that when an Indian says yes he can in fact mean no. The fact that when an Indian says one day, it could mean one week, one he says one week, it could mean one month. That they never deliver on time is considered as normal." Ronald says: "If you have expectations and he says tomorrow, you expect that and then he doesn't do it tomorrow and you're disappointed, you're getting frustrated,. You shouldn't have expectations from a country as India, that makes life much easier here." The above implies that expatriates such as Klaas and Ronald can be very disappointed when taking their view of time as a reference. We interpret that when Indian expectations are not departing from ones own cultural framework expatriates have more chances to 'succeed'. The results about masculinity are a bit more ambiguous. It seems that the level of masculinity in the non-work environment is higher than in the work environment. Otto indicates: “in business I have the idea that they're (women) treated the same, I see not much difference between men and women. You do see more men in important functions, but I've seen women as well in management functions. There are women who command respect. They just do their work excellent and they won't hesitate to reprimand (male) subordinates." However, there seem to be differences between rural areas and urban areas; in urban areas the level of masculinity in the non-work environment seems to be higher than the level of masculinity in the non-work environment in urban areas. respondent Niels indicates: "what you do notice, not in the metropolis but in the rural areas is that the man simply is the boss and in some states the woman walks behind her husband. But I think that if you look at where we lived, in Delhi, in Bombay, just as in The Netherlands relations are not completely balanced but where the woman is behind closed doors the boss just like here, as they say, but the streets are mainly dominated by men there are not that many women." These excerpts demonstrate that although there are enough (competent) women in management positions traditional gender relations still pre-dominate in both rural areas and in private settings as emphasized by Niels' wording of 'man simply being the boss'. These quotes indicate 
that inclusion of masculinity in a CCT extensively is important if the expatriate goes to a rural area. The results about collectivism are ambiguous as well. Within the private lives of Indians the level of collectivism is high. However, it appears to be difficult to say whether there is a collectivistic mindset within companies. There seems to be a dichotomy between the companies in India. Some have a collectivistic mindset, while others have not. It is therefore important to mention collectivism in a CCT program. In that way the expatriates will be prepared for the fact that although the Indian society is collectivistic, this might be different in the company they work for. However, this subject should not be treated too extensively. Uncertainty avoidance should be treated as well in a CCT program. Respondent Queen, working for a multinational in an urban area, tells: “we always think 'if this would happen, what I can do?' We are always prepared for the worst because we want to be sure that everything will be fine. In India it's more like oh, it's just not organized, everything can happen and if it happens we'll see what we do. (...) Real problems you experience are problems you will never experience in The Netherlands, because we made that it couldn't happen and we have all those rules. Because there are no rules here everything can happen, everything you can imagine can go wrong.." This implies that although there are rules in India, no one keeps the rules. Expatriates find this difficult as they are used to avoiding uncertainty by strict rules. The particularistic nature of Indians should be treated extensively in a CCT program since the results show that this dimension can be expected to give rise to problems. Anne, working for an Indian company in a rural area, indicates: "there only is cronyism", and “(...) in my company it wasn't that bad, but I know that in other companies completely incompetent people have important functions and they're appointed by the director, which is his cousin or his brother. Men of course. So you can't reprimand him. You can't. He's always right and you're not." Fred, working for a multinational in an urban area, says: "it's all about who you know." So we interpret here that the expatriates we interviewed really had to get adjusted to the fact that in India working through family relations is important. The diffused character of India should not be implemented in a CCT program. The results of this study show that this dimension is almost not experienced by the respondents. 
The third group of elements concerns elements regarding the Indian context. It seems possible that Dutch expatriates will notice influences of religion when they are in India. These influences can be noticed at work as well as in the non-work environment. However, since only half of the respondents indicate that they noticed influences of religion, religion should not be treated too extensively in a CCT. Some basics about Hinduism and about the possible tensions among the different religions seem to be sufficient. Ronald, working for a Dutch company in an urban area, gives an example on how he noticed Hinduism in the work environment: "the religious background is always visible. The first time a half product enters the factory there are sacrifices, like flowers for example. They were made in favor of a positive outcome of the assembly process. Or the tree that cannot be cut down because it is a tree. But never the less it's right in front of a loading dock."

\section{TABLE 4}

\section{Level of attention needed for different elements in CCT for Dutch expatriates in} India (part 2)

\section{Elements in CCT for Dutch expatriates in India}

\begin{tabular}{|c|c|}
\hline Regarding the Indian context & Regarding the Indian culture \\
\hline $\begin{array}{l}\text { Religion } \\
\text { Just mention }\end{array}$ & $\begin{array}{l}\text { Power distance } \\
\text { Treat extensively }\end{array}$ \\
\hline $\begin{array}{l}\text { Poverty } \\
\text { Treat extensively }\end{array}$ & $\begin{array}{l}\text { Ascription oriented } \\
\text { Just mention }\end{array}$ \\
\hline $\begin{array}{l}\text { Caste system } \\
\text { Depending on region; going to an urban region: just } \\
\text { mention. Going to a rural area: treat extensively }\end{array}$ & $\begin{array}{l}\text { Short term orientation } \\
\text { Just mention } \\
\text { Sequential vs. synchronous view of time }\end{array}$ \\
\hline $\begin{array}{l}\text { Corruption } \\
\text { Treat extensively }\end{array}$ & $\begin{array}{l}\text { Treat extensively } \\
\text { Masculinity }\end{array}$ \\
\hline $\begin{array}{l}\text { Bureaucracy } \\
\text { Just mention }\end{array}$ & $\begin{array}{l}\text { Depending on region; going to an urban area: just } \\
\text { mention. Going to a rural area: treat extensively }\end{array}$ \\
\hline $\begin{array}{cl}\text { Other } & \\
- & \text { Healthcare } \\
& \text { Just mention } \\
\text { - } & \text { White tax } \\
& \text { Just mention; only when going to an urban } \\
& \text { area }\end{array}$ & $\begin{array}{l}\text { Collectivism } \\
\text { Just mention } \\
\text { Uncertainty avoidance } \\
\text { Just mention } \\
\\
\text { Particularistic } \\
\text { Treat extensively }\end{array}$ \\
\hline
\end{tabular}


This shows the influence of religion in the work environment. As can be seen, this can go pretty far. If there is a tree right in front of a loading dock, the tree has to be cut. However, because of the religion the tree cannot be cut. This is a delicate situation. If the expatriate just orders to cut the tree, there is a risk that the Hindus among the employees are offended, this can lead to awkward situations.”

The element poverty in general should be treated extensively in a CCT program, and it should be pointed out to all expatriates. The results show that most expatriates have and keep having difficulties when being confronted with poverty in India. Carine says: "(...) you know that you go to an area where people are poor, but when you see this poverty every day, it is still a shock." As Carine says being confronted with poverty daily is still a shock. The existence of organized groups of beggars is likely to be only relevant for expatriates going to urban areas in India. Regarding the latter it is therefore important to take the region the expatriate is going to into consideration. For the caste system the region the expatriate is going to should be taken into consideration as well. When he/she go to a metropolis, a brief introduction to the caste system seems be sufficient. However, if the expatriate goes to a rural area, the CCT regarding the caste system should be more extensive. Anne, living in a rural area, indicates with regard to the caste system: "it's officially abolished, but in reality absolutely not. This uttering implies that influences of the caste system are still observed at work, and expatriates ought to know this as to handle social issues during their expatriation adequately. Corruption should be treated extensively in a CCT program for Dutch expatriates going to India. When dealing with corruption consciously, it is less likely that expatriates will cross the thin line between ethical and unethical behavior. Carine says: "it's hard to be not corrupt and to manage to do something at the same time. You always need authorities which have to give permission for something. And if you're really strict you won't reach anything. So you have to do something. But you have to be careful to not to behave unethical." This suggests that these expatriates experience they have to behave unethically as to achieve things. However this also shows how people from diverse cultures may define ethics differently and that it is difficult to impose (upon) expatriates their own norms in other contexts. Bureaucracy should also be part of a CCT program. However, it should be mentioned briefly, since knowledge about bureaucracy cannot prevent bureaucracy from 
happening. It can only make that the expatriates realize that they just have to except it when confronted with bureaucracy because it is an important element of the Indian context. John, who lived in an urban area, for example indicates: “(..) everything is forcedly structured here, bureaucratic, everything with ten signatures from one official to the other. That makes that the society is quite laborious and broken into parts and that doesn't make it easy. Especially for expats who are settling and who have to go through all this bureaucratic paperwork, it all takes, even with help of specialized people, a lot of time. And that sometimes gives some irritation.." To conclude, there are two other, small elements of the Indian context which should be treated in a CCT program. The first element is healthcare. Regarding healthcare in a CCT program it should be mentioned that within urban areas it might be better to go to a private hospital instead of to a state hospital that can be unorganized, unhygienic and abysmal. The second element is the so called 'white tax'. This element is only relevant for expatriates going to urban areas in India. Respondent Fred, Otto, and Piet indicate that expatriates pay more as locals in India. Respondent Otto says: "it means that you always pay more. It's of course no official tax, but do take into account that you'll pay more." Respondent Fred indicates: "they (expatriates) pay much more for the maid, for the nanny, as I pay, and they pay more for the servants, or the driver, as I do for mine." This means that expatriates experience a different treatment from the Indians when paying for anything in India.

By including the identified elements (Table 3, Table 4) in a more specific CCT program for Dutch expatriates going to India, a better international adjustment of Dutch expatriates may be reached, and lead to a decrease in the failure rate of expatriate assignments in India. Moreover Dutch expatriates going to India may be more able to adequately handle the challenges they meet in India.

\section{CONCLUSIONS}

The aim of this study was to gain insight in the challenges Dutch expatriates encounter during their stay in India, and in the way CCT can be improved in order to handle these challenges adequately. 
This study indicates that in order to improve CCT for Dutch expatriates going to India, training approaches such as cultural awareness training, attribution training, didactic training and language training are suitable. Instruction strategies should preferably be participatory approaches such as role play and simulations that require active participation of the expatriate. An good alternative are case studies. The contents of the CCT should be split up in the five areas: adjustment to work; adjustment to interacting with host country nationals; adjustment to the general non-work environment adjustment to the Indian culture, and adjustment to the Indian context. For each area the distinguished elements should form the basis of the training (Brewster \& Scullion, 1997, Russell, 2006) such as for example adjustment to work, to interacting with HCNs as domestic personnel, to the non-work environment, to power distance, to a synchronous view of time, to low uncertainty avoidance, to particularism, to poverty, to the caste system, to bureaucracy, to corruption and to white tax..

Since the main reason for expatriate failure seems to be the inability of the expatriate to adapt to the foreign environment (McDonald, 1993; Anderson, 2003), rather than a lack of technical skills (McDonald, 1993), the improved CCT for Dutch expatriates going to India might lead to a lower failure rate of expatriate assignments since CCT has a substantial positive influence on international adjustment (Black and Mendenhall, 1990; Forster, 2000; Anderson, 2005; Tung, 1987). When including the elements shown in table 3, the international adjustment of a Dutch expatriate in India regarding work, interacting with HCNs, and the general non-work environment is likely to increase. Moreover, when including elements specifically related to the Indian culture and context, which are shown in table 4, the level of international adjustment is likely to increase even more since the Indian culture and context will have an influence on work, interacting with HCNs, and the general non-work environment. In a CCT course extensively treated should be elements such as for example bureaucracy and corruption, interacting with HCNs as domestic personnel, power cuts, safety, practical issues, poverty, power distance, synchronous view of time, and particularism. It is enough only to mention elements such as for example: interacting with $\mathrm{HCN}$ in a social environment, religion, health care, white tax, collectivism, and uncertainty avoidance. 
Most of the elements found in this study are in line with the findings of Morley \& Flynn (2003). However, the findings of Morley \& Flynn (2003) do not take the country the expatriate is going to into consideration. The findings of this study, being situated in India, do take the country the expatriate is going to into consideration. Where Morley \& Flynn (2003) for example indicate that culture shock is one of the challenges an expatriate faces, this study identifies concrete elements of the Indian culture which can form a challenge for the Dutch expatriate. In other words, this study identifies elements which can cause this culture shock for Dutch expatriates located in India. The knowledge derived from this concrete focus on a particular country especially forms the added value of this study.

The most important limitation of this research is the fact that India in general is the subject of this research. During the interviews appeared that there seem to be large differences between the different regions and cities in India. Yet, as there was hardly any research available on this topic we decided to firstly explore on broad lines. A suggestion for further research is to conduct another study, this time focused on either rural areas in India or on urban areas.

Moreover, since several expatriates indicated that there are large differences between urban areas, a new study with different metropolis as subject, such as Delhi, Mumbai, and Bangalore, which are cities a lot of expatriates are sent to, is suggested. This new research will lead to a clear view on the different cities, and on the problems and challenges Dutch expatriates will probably encounter in that city. Knowing these elements per city makes it possible to focus on the city the expatriate is going to, instead of focusing India as a whole. This will give the expatriate an even better preparation for his stay in India, which might further decrease the failure rate.

We finally think studying the differences between male and female expatriates might produce new insights and contribute to the scarce knowledge of the relation between gender and expatriation. 


\section{REFERENCES}

Amin, M., \& Mattoo, A. 2008. Human capital and the changing structure of the Indian economy. Washington: World Bank.

Anderson, B.A. 2005. Expatriate selection: good management or good luck? International Journal of Human Resource Management, 16 (4), 567-583.

Anderson, A.W. 2003. Expatriate adjustment to foreign assignments. International Journal of Commerce and Management, 13 (1), 42-60.

Baskerville, R.F. 2003. Hofstede never studied culture. Accounting, Organizations and Society, 28, 1-14.

Bennett, R., Aston, A. and Colquhoun, T, 2000. CCT: a critical step in ensuring the success of international assignments. Human Resource Management, 39 (2 \& 3), 239-250.

Bhawuk, D.P.S., and Brislin, R.W. 2000. Cross-cultural training: A review. Applied Psychology, 49, 162-191.

Black, J.S., and Gregersen, H.B. 1991. Antecedents to cross-cultural adjustment for expatriates in Pacific Rim assignments. Human Relations, 44 (5), 497-515.

Black, J.S., and Gregersen, H.B. 1999. The right way to manage expats. Harvard Business Review, March/April, 52-62.

Black, J.S., and Mendenhall, M. 1990. CCT effectiveness: A review and theoretical framework for future research. The Academy of Management review, 15 (1), 113136.

Black, J.S., Mendenhall, M., and Oddou, G. 1991. Toward a Comprehensive Model of International Adjustment: An Integration of Multiple Theoretical Perspectives. The Academy of Management Review, 16 (2), 291-317.

Brewster, C., and Pickard, J. 1994. Evaluating expatriate training. International Studies of Management and Organization, 24 (3), 18-35.

Brewster, C., and Scullion, H. 1997. A review and agenda for expatriate HRM. Human Resource Management Journal, 7 (3), 32-41.

Fontaine, G. 1994. Training for the Key Challenges Encountered on International Assignments in Asia and the Pacific. [WWW document]. URL: http://www2.hawaii.edu/ fontaine/uispabsBangkok.html. (Visited January 22, 2008). 
Forster, N. 2000. Expatriates and the impact of CCT. Human Resource Management Journal, 10 (3), 63-78.

Fowler, S. and Blohm, J.M. 2004. An analysis of methods for intercultural training. In D.Landis, J.M.Bennett and M.J.Bennett (Eds.) Handbook of intercultural training ( $3^{\text {rd }}$ edition). Thousand Oaks: Sage, 37-84.

Hampden-Turner, C.M., and Trompenaars, F. 2000. Building Cross-cultural competence. Chichester: John Wiley \& Sons.

Hampden-Turner, C. and Trompenaars, F. 2006. Cultural Intelligence: Is such a capacity credible? Group \& Organization Management, 31(1), 56-63.

Harzing, A. 2001. Of Bears, Bumble-Bees, and Spiders: The Role of Expatriates in controlling Foreign Subsidiaries. Journal of World Business, 36 (4), 366-379.

Hofstede, G. 1991. Cultures and Organizations: Software of the Mind. Intercultural Cooperation and its Importance for Survival. London: McGraw-Hill.

Kemper, E.A., Stringfield, S., and Teddlie, C. 2003. 'Mixed Methods Sampling Strategies in Social Science Research', in Tashakkori, A., and Teddlie, C. (eds.) Handbook of mixed methods in social and behavioral research (pp. 273-296). Thousand Oaks: Sage.

Koen, C.I. 2005. Comparative International Management. Berkshire: McGraw-Hill Education.

Landis, D., Bennett, J.M., Bennett, M.J. (Eds.) 2004. Handbook of intercultural training ( $3^{\text {rd }}$ edition). Thousand Oaks: Sage.

Littrell, L.N., and Salas, E. 2005. A review of CCT: Best practices, guidelines, and research needs. Human Resource Development Review, 4 (3), 305-334.

Littrell, L.N., Salas, E., Hess, K.P., Paley, M. and Riedel, S. 2006. Expatriate preparation: a critical analysis of 25 years of CCT research. Human Resource Development Review, 5 (3), 355-388.

McDonald, G.M. 1993. ET go home? The successful management of expatriate transfers. Journal of Managerial Psychology, 8 (2), 18-29.

McSweeney, B. 2002. Hofstede's model of national cultural differences and their consequences: A triumph of faith - a failure of analysis. Human Relations, 55(1), 89-118. 
Mendenhall, M.E., Stahl, G.K., Ehnert, I., Oddou, G., Osland, J.S. and Kühlmann, T.M. 2004. Evaluation studies of CCT programs: A review of the literature from 1988 to 2000. In D.Landis, J.M.Bennett and M.J.Bennett (Eds.) Handbook of intercultural training ( $3^{\text {rd }}$ edition). Thousand Oaks: Sage, 129-144.

Mendenhall, M.E., and Oddou, G. 1985. The Dimensions of Expatriate Acculturation: A Review. Academy of Management Review, 10 (1), 39-47.

Mendenhall, M.E., and Oddou, G. 1986. Acculturation Profiles of Expatriate Managers: Implications for CCT Programs. Columbia Journal of World Business, 21 (4), 7379.

Mehta, A. K. and Shah, A. 2003. Chronic poverty in India: incidence, causes, and policies. World Development, 31 (3), 491-511.

Milner, M. 1994. Status and Sacredness. A General Theory of Status Relations and an Analysis of Indian Culture. New York: Oxford University Press.

Morley, M.J., and Flynn, M. 2003. The relationship between work-role characteristics and intercultural transitional adjustment domain patterns among a sample of US and Canadian expatriates on assignment in Ireland. Cross-cultural Management: An International Journal, 10 (3), 42-57.

Morris, M.A. and Robie, C. 2001. A meta-analysis of the effects of cross-cultural training on expatriate performance and adjustment. International Journal of training and Development, 5, 112-125.

Osman-Gani, A. 2000. Developing expatriates for the Asia-Pacific region: A comparative analysis of multinational enterprise managers from five countries across three continents. Human Resource Development Quarterly, 11 (3), 213-236.

Potter, J., and M. Wetherell 1987. Discourse and Social Psychology, London: Sage.

Rothermund, D. 2008. India the rise of an Asian giant. New Haven: Yale University Press.

Russell, R.C. 2006. Expatriate Managers' Immersion in Another Culture: A Phenomenological Study of Lived Experiences. Unpublished doctoral dissertation, Curtin University of Technology, Sydney.

Sappinen, J. 1993. Expatriate adjustment in foreign assignment. European Business Review, 93 (5), 3-11.

Stahl, G., and Björkman, I. 2006. Handbook of Research in International Human Resource Management. Cheltenham: Edward Elgar Publishing Limited. 
Tung, R.L.1987. Expatriate Assignments: Enhancing Success and Minimizing Failure. Academy of Management Executive, 1 (2), 117-25.

Waxin, M. and Panaccio, A. 2005. CCT to facilitate expatriate adjustment: it works! Personnel Review, 34 (1), 51-67.

Wester, F. and Peters, V. 2004. Kwalitatieve Analyse. Uitgangspunten en procedures. Bussum: Uitgeverij Coutinho BV.

Zucal, B., and Talani, A. 2004. International Assignments: Reducing Risk, Ensuring Success. Innovations in International HR, Summer 2004, 5-8. 